\title{
Motives Underlying Recreational Alcohol and Cannabis Consumption
}

\author{
Muhamad Salis Yuniardi ${ }^{1}$, Jacqueline Rodgers ${ }^{2}$, Mark Freeston ${ }^{3}$ \\ ${ }^{1}$ Psychology Faculty, University of Muhammadiyah Malang, Jawa Timur, Indonesia, ${ }^{2}$ In- \\ stitute of Neuroscience, Newcastle University, United Kingdom, ${ }^{3}$ School of Psychology, \\ Newcastle University, United Kingdom
}

\begin{abstract}
The Newcastle Substance Use Questionnaire (NSUQ) Motive section is developed based on a novel theoretical background which is instrumental motives. This study aimed to investigate the latent factor structure of the motives of alcohol and cannabis use. There were 285 participants completing the NSUQ-Alcohol, while 62 of them also answered the NSUQ-Cannabis. Exploratory factor analysis (EFA) was performed through FACTOR version 9.2. The NSUQ-Alcohol motives consisted of 14 items. Three-factor model was retained: the social factor explained the largest variance (3.28), being followed by the perspective taking (3.13) and lastly, the sexual motive (1.85). The NSUQ-Cannabis motives comprised of 16 items which was divided also into three factors. The perspective taking factor contributed the most variance (2.72), being followed by the social motive factor (2.47) and the physical motive factor (1.05). These factors may reflect motives of students consuming alcohol and cannabis recreationally.
\end{abstract}

Key words: instrumental motives, recreational substance use, alcohol motives, cannabis motives

Copyright @ 2021 KBCSM, Zagreb

e-mail: alcoholism.kbcsm@gmail.com•www.http://apr.kbcsm.hr

\section{Introduction}

Nowadays, substance use, particularly among young people or students, is a major issue being encountered by countless countries worldwide. Several studies employing student samples reported a range of negative effects in relation to substance use: low academic achievement and unplanned sex [1] troubles with law enforcement agencies [2], or physical illness [3].

\section{Correspondence to:}

Muhamad Salis Yuniardi, M.Psi., Ph.D.

Fakultas Psikologi UMM. Kampus III. Jl. Raya Tlogomas

No: 246 Malang, Jawa Timur, Indonesia

e-mail: salis@umm.ac.id
Various authors propose that individuals take substances for a variety of motives, what underlies the decision to use a substance or not. According to Cox and Klinger, there are four types of substance use motives that are constructed from two dimensions: outcome (positive-negative) and source (internal-external) [4].

In contrast, a recent review by Múller and Schumann [5] proposed a more sophisticated account. They developed nine motives to assess the extent to which people are motivated to consume substances based on the customer's perception of the impact of those 
substances upon mental and physical states: improving social interaction; facilitating sexual behaviors; improving cognitive performance and counteracting fatigue; facilitating recovery from and coping with psychological stress; self-medication for mental health problems; expanding perceptual horizons; becoming euphoric; improving the physical appearance and attractiveness; and facilitating spiritual and religious activities. They gave examples: on the one hand, CNS depressants such as alcohol are commonly used to facilitate social interaction due to their ability to reduce anxiety and increase talkativeness. On the other hand, stimulants, for instance amphetamine and MDMA, are more commonly used by students to enhance academic performance. Finally, psychedelic substances are frequently used as a part of meditation and rituals in some cultures and religions.

The NSUQ - Motive section was developed based on this novel construct and thus, it was based on a deductive approach. It began with a relevant literature review to fully understand the phenomenon to be investigated, specifically reviewing the theoretical framework of instrumental drug use proposed by Müller and Schumann [5]. Subsequently, the theoretical definition of each instrumental motive was used as the guidance for item generation. Four items were created representing each motive and thus, there were 36 items in total. The content validity of the items was analyzed by means of a series of in-depth discussions involving the authors. A consideration to reduce the number of items representing instrumental motives was taken in accordance with the efficiency principle. Two items that had the most content adequacy were retained for each motive. The exception was only related to the improving physical attractiveness motive which is rep- resented by a single item, due to its exclusive definition (control weight to improve physical attractiveness). All the items were rated on a 5 -point scale $(1=$ not at all like me, $2=$ not much like me, $3=$ somewhat like me, $4=$ quite a lot like me, 5 = just like me).

Although it is based on the recent notion of multiple instrumental motives underlying substance use, there has not been any empirical studies regarding this framework. Consequently, there are no clear predictions as to the likely factor structure underlying the NSUQ-Motive section. Alcohol and cannabis were selected to be analyzed given that one represents a legal and the other represents an illegal substance. Moreover, according to surveys in the UK [6], they are the most popular substances consumed, particularly by students, and thus, are worthy of investigation. Although some studies have compared motives behind the use of alcohol and cannabis $[7,8]$, none have yet examined these using the instrumental motive framework. Therefore, the current study aims to investigate the latent factor structure of motives for both substances.

\section{Methods}

\section{Participants}

There were 397 students, who were recruited from five universities in the North and North East of the UK, participated in this study. However, only 285 participants completed the online questionnaire and reporting that they consumed alcohol in the past year, and there were 62 participants reporting that they used alcohol and cannabis in the last 12 months. The study was approved by the Ethics Committee of the Faculty of Medical Sciences at Newcastle University. 


\section{Data analysis}

The exploratory factor analyses were conducted using FACTOR version 9.2 which is not only a user-friendly program, but also includes several recent developments in factor analytic approaches [9].

\section{Results}

\section{The NSUQ-Alcohol Motives section}

Analyzes was conducted on a sample of 285 participants who reported alcohol use within the past year. Initial inspection of the distribution of each item showed that the distributions of nine items were positively skewed $(>1.0)$. Skewness affects statistical estimations and subsequently model fitting [10]. Therefore, the polychoric correlation matrix, which assumes an underlying continuous distribution, was used. In addition, the coefficient of multivariate asymmetry skewness was not significant $(\mathrm{p}=1.00)$, however the coefficient of multivariate asymmetry kurtosis was highly significant $(p<0.001)$. Based on multivariate normality analysis proposed by Mardia [11], this data was categorized as kurtotic. Violation to multivariate normality could also support utilizing the polychoric correlation [12].

There was only one high inter-correlation ( $r=$ 0.85) between item 1, "I drink alcohol because it helps me feel more confident", and item 7, "... it helps me be less anxious around people". This is unsurprising because both items are designed to measure the same motive: improving social interactions. Three items, namely, item 14 (... it helps me control my weight), item 15 (... it is part of a ritual in my culture/ religion), and item 17 (... it helps me feel more spiritual) had low $(\mathrm{r}<0.20)$ or no significant correlations $(r=0.00)$ with many other items. Most inter-correlations for all other items were in the range of weak to moderate level while the remaining few were $>0.50$. The determinant of the matrix was 0.00025 (>0.00001), indicating that generally multicollinearity was not present [13].

Three items: items 14, 15 and 17, were dropped for both conceptual and empirical reasons. In terms of the conceptual reason, item 14 was dropped as alcohol is not frequently used to control weight, indeed it may lead to an increase in weight due to the amount of calories consumed (for instance: an average pint of 5\% strength beer has 170 kilo calories) [14]. Items 15 and 17 were eliminated given that alcohol is not a type of substances commonly being used as part of a religious ritual or spiritual activities $[5,15,16]$. In terms of the empirical reason, these three items were highly positively skewed $(>1.90)$ and kurtotic $(>3.00)$ given that very few people endorsed these motives.

As a result of dropping these items, the participant to item ratio was greater than 20:1, indicating that the sample size was adequate. Despite eliminating those items with the most extreme skew and kurtosis, the distributions of six items still remained skewed $(>1.00)$, whilst two items demonstrated high kurtotis $(>3.00)$. Therefore, use of the polychoric correlation matrix was still indicated.

The determinant of the matrix of the remaining 14 items was 0.00057 (> 0.00001), indicating multicollinearity was not present. The Kaiser-Meyer-Olkin (KMO) test was .88 (good) and the Bartlett's statistic was 2082 $(\mathrm{df}=91 ; \mathrm{p}<0.001)$. A KMO statistic $>0.80$ and a significant Bartlett's test indicated that the matrix was suitable for factor extraction [17]. Therefore, the remaining 14 items were retained for all subsequent analyses. 
The next step was deciding the number of factors to retain. This study used three of perhaps the best-known criteria to decide on the number of factors retained: Kaiser's criterion, the scree plot and parallel analysis based on Minimum Rank Factor Analysis (PA-MRFA) which is the default method within FACTORS. Relying on multiple criteria and examining multiple solutions offered until finding the most interpretable solutions is considered as the best strategy [18-20]. According to Kaiser's criterion [21], all components with eigenvalues $<1.00$ should be excluded; therefore, in this case three factors were suggested to be retained. The scree plot indicated that two factors situated before the line started at 'the elbow' afterward and became flat after the third factor. However, PAMRFA advised one solution.

Given this discrepancy, factors were extracted on all three possible models using Unweighted Least Squares (ULS) which is considered more robust if the assumption of multivariate normality is severely violated [22]. Several authors argue that most factor extraction methods cannot compute the percentage of common variance explained, including ULS $[9,23,24]$. They argue that only
Minimum Rank Factor Analysis (MRFA), which is under multivariate normality assumption, enables the proportion of variance explained by each factor to be computed. Therefore, in following these recommendations the variance explained will be reported, but not as a percentage of the total.

Indices of fit was used to guide decisions concerning the adequacy of a solution. Since each of the fit indices has different strengths and weaknesses, this study relied on double criteria: The Goodness-of-Fit Index (GFI) and The Root Mean Square of Residuals (RMSR). According to Cole [25], GFI > 0.9 indicates a well-fitting model and RMSR < 0.10 is arguably considered sufficient.

As can be seen in Table 1, the three-factor model emerged with better goodness-of-fit statistics compared with the two other models. The three-factor model demonstrated an excellent fit (Goodness of Fit Index =0.99) and it's residual (Root Mean Square of Residual $/$ RMSR $=5.01 \%$ ) was smaller than other models.

Direct oblimin rotation was used to achieve factor simplicity. It allows correlations amongst factors, and, thus, is more suitable for social sciences as constructs in the

Table 1. Features of three suggested solutions of the 14 items-NSUQ-Alcohol

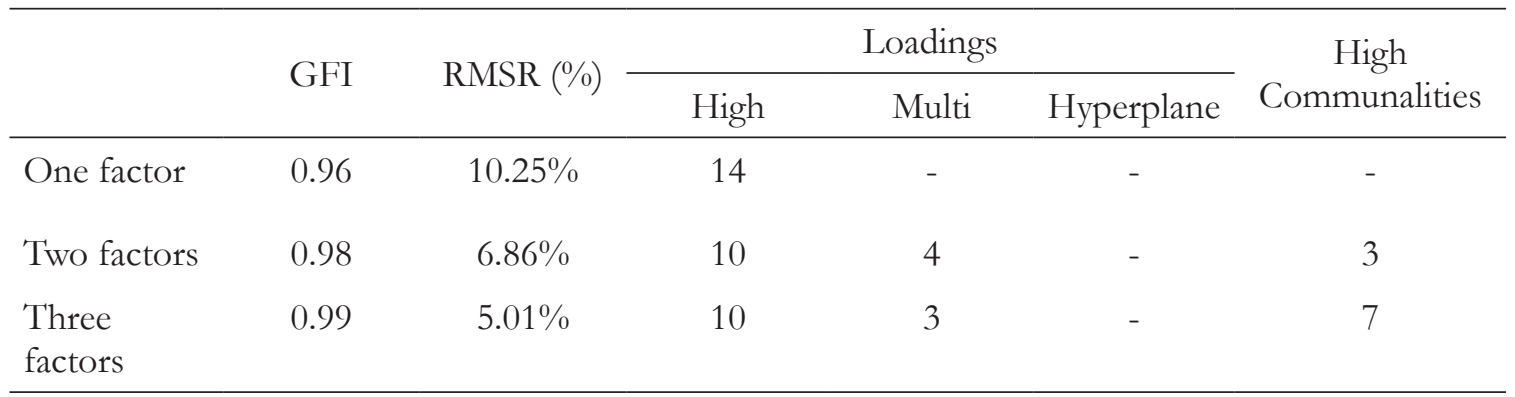

GFI - goodness of fit index ; RMSR - root mean square of residual 
Table 2. Factor loadings ( $\geq 0.30)$, explained variance and reliability of rotated factors for the NSUQ-Alcohol Motives-14 item version.

\begin{tabular}{|c|c|c|c|c|c|c|c|c|c|c|}
\hline \multirow{2}{*}{ No } & \multirow{2}{*}{ Items } & \multicolumn{2}{|c|}{ One-factor } & \multicolumn{3}{|c|}{ Two-factor } & \multicolumn{4}{|c|}{ Three-factor } \\
\hline & & I & Com & $\mathrm{I}$ & II & Com & I & II & III & Com \\
\hline 1 & $\begin{array}{l}\text { I drink alcohol } \\
\text { because it helps } \\
\text { me feel more con- } \\
\text { fident }\end{array}$ & 0.70 & 0.49 & 0.96 & -0.08 & 0.84 & 0.95 & -0.06 & -0.02 & 0.83 \\
\hline 7 & $\begin{array}{l}\text { helps me be less } \\
\text { anxious around } \\
\text { people }\end{array}$ & 0.71 & 0.50 & 0.87 & 0.00 & 0.75 & 0.86 & -0.03 & 0.04 & 0.74 \\
\hline 3 & $\begin{array}{l}\text { makes me feel } \\
\text { relaxed }\end{array}$ & 0.67 & 0.44 & 0.61 & 0.16 & 0.52 & 0.62 & 0.18 & -0.02 & 0.52 \\
\hline 13 & $\begin{array}{l}\text { makes me high/ } \\
\text { drunk/stoned }\end{array}$ & 0.63 & 0.40 & 0.56 & 0.18 & 0.46 & 0.58 & 0.05 & 0.14 & 0.46 \\
\hline 10 & $\begin{array}{l}\text { helps me feel } \\
\text { euphoric }\end{array}$ & 0.69 & 0.47 & 0.38 & 0.39 & 0.47 & 0.41 & 0.27 & 0.15 & 0.46 \\
\hline 2 & $\begin{array}{l}\text { helps me think } \\
\text { more clearly }\end{array}$ & 0.64 & 0.41 & 0.02 & 0.68 & 0.48 & 0.00 & 0.83 & -0.10 & 0.61 \\
\hline 11 & $\begin{array}{l}\text { gives me mental } \\
\text { boost }\end{array}$ & 0.68 & 0.46 & -0.10 & 0.85 & 0.63 & -0.08 & 0.75 & 0.15 & 0.64 \\
\hline 6 & $\begin{array}{l}\text { makes me feel cre- } \\
\text { ative or inspired }\end{array}$ & 0.68 & 0.46 & -0.03 & 0.78 & 0.58 & -0.02 & 0.74 & 0.09 & 0.61 \\
\hline 4 & $\begin{array}{l}\text { helps me look at } \\
\text { things differently }\end{array}$ & 0.73 & 0.54 & 0.36 & 0.47 & 0.53 & 0.36 & 0.54 & -0.07 & 0.58 \\
\hline 5 & $\begin{array}{l}\text { helps me reduce } \\
\text { tiredness }\end{array}$ & 0.55 & 0.31 & 0.00 & 0.60 & 0.36 & 0.03 & 0.48 & 0.15 & 0.35 \\
\hline 8 & $\begin{array}{l}\text { helps me when I } \\
\text { feel low or down }\end{array}$ & 0.74 & 0.55 & 0.34 & 0.49 & 0.53 & 0.36 & 0.37 & 0.14 & 0.53 \\
\hline 16 & $\begin{array}{l}\text { helps me feel less } \\
\text { upset }\end{array}$ & 0.65 & 0.42 & 0.29 & 0.43 & 0.41 & 0.31 & 0.35 & 0.10 & 0.41 \\
\hline 9 & $\begin{array}{l}\text { increases my } \\
\text { sexual desire }\end{array}$ & 0.58 & 0.33 & 0.02 & 0.61 & 0.39 & 0.00 & -0.02 & 0.89 & 0.77 \\
\hline 12 & $\begin{array}{l}\text { increases my } \\
\text { sexual stamina }\end{array}$ & 0.61 & 0.38 & 0.04 & 0.64 & 0.43 & 0.03 & 0.05 & 0.81 & 0.73 \\
\hline Expl & lained variance & 6.15 & & 3.22 & 4.16 & & 3.28 & 3.13 & 1.85 & \\
\hline Relia & ability $($ Cronbach $\alpha)$ & 0.92 & & 0.92 & 0.89 & & 0.91 & 0.86 & 0.86 & \\
\hline
\end{tabular}

Com - communality 
real world are rarely uncorrelated [22]. There is no single rule of thumb regarding a minimum magnitude of variable loading that is considered significant and meaningful. Previous authors have previously proposed, $>0.50$ [26], $>0.40$ [19], or $>0.30$ [27]. Given the exploratory nature of this study, this analysis considered items with loadings greater than 0.30 and emphasized particularly items having larger loadings $(>0.50)$ in interpretation and naming factors.

For all three possible models, there were no "hyperplane" item, that is, no items that did not load on any factor $(\leq 0.30)$. For the one-factor model, all items were loaded strongly $(>0.50)$ to the single available factor. There were no high communality items $(>0.60)$. For the two-factor model, 10 items loaded robustly on their corresponding factors. However, four items loaded on double factors and only three items had high communalities. For the three-factor model, ten items were robustly loaded on their corresponding factor. Only three items showed multiple loadings, while there were seven items with high communality $(>0.60)$. The three-factor model was superior in loadings and in terms of the number of items with high communalities. Inspection of the items indicated that the three-factor model is interpretable. Therefore, the three-factor model was retained because of superior fit indices, simpler structure and high communalities.

Following recommendations by Rummel should be considered when naming factors: (i) communication to others. (ii) mnemonic or how easy the label would be recalled, and (iii) future use or the expediency of any future use [28].

For the three-factor model, factor 1 consisted of five items. The two largest loading items clearly described alcohol as a "social lubricant", helping people to get along well with others. The three remaining items, specifically, being relaxed, high and euphoric, represented emotionally positive outcomes frequently associated with social situation as well. Thus, "social-motives" was considered as the most appropriate label for and it accounted for the most variance (3.28).

Factor 2 consisted of seven items. Three strongly loading items represented improved perspective taking motives. An item, "I drink alcohol because it gives me mental boost", represented mental recovery. A further item, "I drink alcohol because it helps me reduce tiredness", represented recovering from fatigue. The two remaining items had weak loadings and depicted emotional coping. Based on the majority of strongly loading items, this factor was named "perspective taking motives". The perspective taking factor accounted for (3.13) almost as much variance as the social factor.

Factor 3 comprised only two items: "I drink alcohol because it increases my sexual desire" and "I drink alcohol because it increases my sexual stamina". Both items clearly represented a thought that alcohol is believed to facilitate sexual activities. This factor contributed considerably less variance (1.85) than the other two factors.

Social motives correlated with the perspective taking motives and the sexual motives, $r=0.42$ and $r=0.53$, respectively. The perspective taking motives also correlated with the sexual motives, $\mathrm{r}=0.55$.

\section{The NSUQ-Cannabis Motives section}

Sixty two participants who had consumed cannabis in the last 12 months were involved in this part. Of the original 17 items, 10 of the items were positively skewed $(>1.0)$, seven items were positively kurtotic and one item was negatively kurtotic. Consequently 
the polychoric correlation matrix was more appropriate [10]. In addition, nearly half of the correlations fell into the 0.3 to 0.5 range (moderate), only two correlations were considered strong $(>0.5)$, whereas the rest of the correlations were weak $(<0.3)$.

The determinant of the matrix was $0.00002(>0.00001)$, the Kaiser-MeyerOlkin (KMO) test was 0.82 (good) and the Bartlett's statistic was now 595.6 ( df $=136$; $p$ $=0.000010)$. Hence, all three indicators indicated that the matrix was suitable.

Though some item distributions were quite strongly positively skewed $(>2.0)$, all the items conceptually portrayed what people might perceive in relation to the possible impact of cannabis on their mental or physical states. For instance, in contrast to alcohol, people may use cannabis to control weight [29] or as part of their religion [30]. Hence, in contrast to alcohol where three items (item 14: control weight, item 15: part of ritual/ religion; item 15: help to feel more spiritual) were dropped on conceptual and empirical grounds, all 17 items were retained for entire further analyses.

The participant to item ratio was 3.651: 1 which violates some rules of thumbs about participant numbers [26] and/or participant to item ratios $[27,31]$. The rule of thumb regarding sample size for factor analysis could be summed up as "the more, the better". However, Guadagnoli and Velicer [32] argued that sample size is not the only single determinant of the factor solution stability, and so carefully selecting variables that strongly load to corresponding factors is recommended more than simply increasing the sample size. MacCallum and Tucker [33] and Macclum and associates [34] demonstrated that deriving a prior definitive decision regarding a minimum sample size appropriate in all situa- tions is impossible. They concluded that factors can be defined well if all variables have high communalities $(>0.6)$ and each factor has at least three strongly loading items, even with relatively small sample sizes.

Each method of selecting the number of extracted factors indicated a different number of factors. Kaiser's criterion displayed three factors with eigenvalues $>1.00$ (see table 4), the scree plot indicated either two or three factors, however PA-MRFA pointed to one factor.

Since each of methods proposed different solutions, extraction was performed upon all three factor solutions suggested. Given that the coefficient of multivariate asymmetry kurtosis was significant $(\mathrm{p}<0.001)$, Unweighted Least Squares (ULS) extraction was used. Direct oblimin rotation was once again used as it allows inter-correlations amongst factors.

Table 3 shows that the three-factor model demonstrated better statistical features than other models. It had excellent goodness of fit $(\mathrm{GFI}=0.99)$ and smaller proportion of residual (Root Mean Square of Residual/ RMSR $=2.87$ ). Item 15 did not load sufficiently $(\leq 0.30)$ on any factor across the proposed models, perhaps due to its weak correlations $(<0.20)$ with all other items. According to Floyd and Widaman [27] "If an item does not correlate at least moderately (e.g., $r=$ 0.20 or greater) with other items for the construct, then the item will likely perform poorly in a factor analysis." Therefore this 'hyperplane' item, which refers explicitly to ritual (in contrast to the other religious instrumental motive item, item 17 , which refers more broadly to spirituality), was deleted. The overall fit for this three-factor model with 16 items was considered good and slightly better than the previous three-factor model, with GFI $=0.099$, RMSR $=2.87 \%$. 
Table 3. Features of three suggested solutions of the 17 item-NSUQ-Cannabis

\begin{tabular}{lcccccc}
\hline & GFI & RMSR $(\%)$ & \multicolumn{3}{c}{ Loadings } & High \\
\cline { 4 - 6 } & & & High & Multi & Hyperplane & Communalities \\
\hline One factor & 0.97 & $6.48 \%$ & 16 & - & 1 \\
Two factors & 0.99 & $3.79 \%$ & 7 & 1 & 2 & - \\
Three factors & 0.99 & $2.91 \%$ & 7 & 2 & 1 & 1 \\
\hline
\end{tabular}

GFI - goodness of fit index ; RMSR - root mean square of residual

Rotation for the remaining 16 items demonstrated that eight items loaded strongly to the corresponding factors $(>0.50)$, one item more than previous rotation. There were two items loaded to two factors as before, but there were no 'hyperplane' items. One item had high communality $(>0.60)$ with eight out of 16 (vs. 7/17) meeting a moderate communality criterion. The 16 -item solution was chosen for interpretation given its slight superiority. The loadings and the communality were displayed in table 4. The 16-item solution was chosen for interpretation given its slight superiority.

Factor 1 consisted of six items and was named "perspective taking motives". The first two items had strong loadings representing the perception that cannabis might facilitate improvement of their perspective taking; making them look at things differently and be more creative. The next two items represented people's thoughts that cannabis makes them more spiritual and provides a mental boost. These were followed by another item that represented perspective taking motives "I use cannabis because it helps me think more clearly". The last remaining item represented a perception that cannabis can make users high. This factor explained the largest variance (2.72).

Factor 2 comprised six items, signified "social motives". No item strongly loaded to this factor $(>0.80)$ and arguably, the four highest loading items loaded equally $(0.53$ - 0.66). The two highest loading items represented the idea that that consuming cannabis might facilitate some positive emotion outcomes, particularly making people more confident and less anxious particularly within social situations. Two other items represented that cannabis is consumed as selfmedication for emotional problems: helping a person when they feel low and increasing their mood. Two remaining items with weaker loadings $(<0.50)$ represented cannabis facilitating recovery from mental stress and to feel euphoric. The amount of the variance explained by the emotional factor (2.47) was slightly lower than the perspective taking factor (2.72).

Factor 3 represented "physical motives" and comprised four items. The highest loading item represented cannabis consumed to improve physical appearance. Of the remaining items, two items portrayed cannabis facilitating sexual desire and stamina, whereas 
Table 4. Factor loadings $(\geq 0.30)$, explained variance and reliability of rotated factors for the NSUQ-Cannabis 16 items.

\begin{tabular}{|c|c|c|c|c|c|}
\hline \multirow{2}{*}{ No } & \multirow{2}{*}{ Items } & \multicolumn{4}{|c|}{ Three-factor } \\
\hline & & I & II & III & Com. \\
\hline 4 & $\begin{array}{l}\text { I use cannabis because it } \\
\text { helps me look at things differently }\end{array}$ & 0.80 & -0.03 & -0.11 & 0.61 \\
\hline 6 & makes me feel creative or inspired & 0.61 & 0.12 & 0.07 & 0.51 \\
\hline 17 & helps me feel more spiritual & 0.55 & -0.02 & 0.18 & 0.33 \\
\hline 11 & gives me mental boost & 0.53 & 0.11 & 0.22 & 0.45 \\
\hline 2 & helps me think more clearly & 0.50 & 0.11 & 0.21 & 0.41 \\
\hline 13 & makes me high/drunk/stoned & 0.42 & 0.16 & -0.40 & 0.41 \\
\hline 1 & helps me feel more confident & -0.05 & 0.66 & 0.10 & 0.42 \\
\hline 7 & helps me be less anxious around people & -0.13 & 0.62 & 0.00 & 0.28 \\
\hline 8 & helps me when I feel low or down & 0.09 & 0.62 & -0.06 & 0.47 \\
\hline 16 & helps me feel less upset & 0.18 & 0.53 & -0.04 & 0.45 \\
\hline 3 & makes me feel relaxed & 0.17 & 0.36 & -0.34 & 0.31 \\
\hline 10 & helps me feel euphoric & 0.27 & 0.34 & -0.09 & 0.32 \\
\hline 14 & helps me control my weight & 0.19 & 0.08 & 0.43 & 0.27 \\
\hline 9 & increases my sexual desire & 0.16 & 0.17 & 0.42 & 0.31 \\
\hline 12 & increases my sexual stamina & 0.15 & 0.32 & 0.33 & 0.35 \\
\hline 5 & helps me reduce tiredness & 0.15 & 0.32 & 0.32 & 0.34 \\
\hline \multicolumn{2}{|c|}{ Explained variance } & 2.72 & 2.47 & 1.05 & \\
\hline \multicolumn{2}{|c|}{ Reliability (Cronbach $\alpha)$} & 0.81 & 0.76 & 0.60 & \\
\hline
\end{tabular}

Com - communality

one item depicted counteracting fatigue. The physical factor explained the smallest amount of variance (1.05).

The perspective taking factor and the physical factor were strongly correlated ( $\mathrm{r}$ $=0.73$ ), while the relationship between the social factor and both the perspective taking and the physical factors were weak, $\mathrm{r}=0.18$ and $\mathrm{r}=0.09$, respectively.

\section{Discussion}

This study primarily aimed to examine the latent structure underlying the motives of the NSUQ, for alcohol and cannabis. The data 
were collected from students, a group who generally consume substances recreationally.

With regards to the NSUQ-Alcohol Motives, the model consisted of 14 items loading on three factors. Factor 1 was specified as the social factor, factor 2 was named the perspective taking factor, while factor 3 , was assigned as the sexual factor. The social factor explained the largest amount variance, followed by the perspective taking factor, and finally, the sexual factor. In addition, all the factors were moderately correlated.

The NSUQ-Cannabis Motives consisted of 16 items and comprised three factors. Factor 1 was named the perspective taking factor, factor 2 was the social factor, whereas factor 3 was the physical factor. Surprisingly, the perspective taking factor explained the most variance, followed by the social factor, with the physical factor being the smallest. The perspective taking factor was strongly correlated to the physical factor, while the social factor, unexpectedly, had a weak correlation with the other two factors.

These three-factor models for both substances reflected potential latent variables underlying the questionnaire items. However, particularly the social and perspective taking motives may also reflect the main motives underlying recreational alcohol and cannabis use amongst student samples. In terms of the social factor, many studies have suggested the importance of social reasons for both alcohol and cannabis use amongst students $[35,36]$. A small number of studies have reported expanded cognitive performance as one of the motives behind alcohol and/or cannabis use among students [7,37,38].

Noticeably one factor was different. The third factor within the NSUQ-Alcohol Motives was the sexual factor consisting of only two items while in the cannabis section, the third factor was a broader four-item physical factor. Items 9 and 12 (representing sexual motives), item 5 (reducing tiredness), and item 14 (controlling weight) made up the physical factor. However, Item 14 had been dropped in the NSUQ-Alcohol Motives as empirically very few participants endorsed these motives. In addition, alcohol is not frequently used to control weight, given it may lead to an increase in weight instead [14]. This case is different with cannabis. People may perceive cannabis as an instrument to control weight [29].

Although the first two factors were labelled social and perspective taking in both cases, the exact items differed; therefore, it is not simply a case of difference in order of appearance. For instance, two items representing alcohol as self-medication for mental problems loaded to the perspective taking factor with weak loadings, while two items representing similar motives for cannabis loaded to the social factor with high loading. Therefore, any substantive interpretation of the factors needs to go beyond the label.

Further, in both cases, the variance accounted for by the first and second factors did not differ greatly. For alcohol, the social factor provided the largest contribution, closely followed by the perspective taking factor. However, in relation to cannabis, the pattern was opposite. However, these results may illustrate the differences in students' perceptions towards both types of substances. Presumably alcohol is seen more as a 'social lubricant', while cannabis is perceived more as a booster of cognitive performance. This assumption appears to be in accordance with Simons and associates, who ascertained that social motives were more strongly related to alcohol use, while 
cognitive enhancement was more strongly related to cannabis use [7].

Moreover, one may question why an emotional coping motive was not one of the more robust factors within the current study. Nevertheless, this question has probably been answered by several studies $[39,40]$ that reported that coping with emotional problems may not be the primary motive for substance use among students, who often use substances recreationally. Instead, they are initially driven more by social reasons to use substances. However, as substance use increases and turns to substance use-related problems, such as abuse or dependence, then coping with negative emotions motive may emerge.

This study has a number of limitations. First, the small number of participants included in the factor analysis of the NSUQCannabis Motive is a significant limitation. Though several experts state that the number of participants in a factor analysis is less important than some other considerations $[27,32-34,41]$, in terms of stability of factor solutions, we believe that "more is still better". Given that the entire sample of this study was 397 and the number of participants who consumed cannabis in the last year was only 62 , in order to increase the sample for those who consume cannabis in order to follow the common rules of thumb about participant number to item ratio which is at least 10:1 [27,31] thus at least 1092 participants would need to be recruited or 2.75 times the current sample. However, it is important to note that the proportion of participants reporting cannabis use in the current study $(20.26 \%)$ was slightly higher than the result established in the national survey $(16 \%)$ [6].

Second, in spite of the practicalities of much larger samples, MacCallum and Tuck- er and MacCallum and associates state that a relatively small sample size does not really matter, as long as factors can be well defined; indicated by the high communalities and strongly loadings of most items [33,34]. Despite strong theoretical underpinnings and a structure that was broadly interpretable, the factor analysis for the NSUQ-Cannabis Motives did not meet these two criteria; therefore, the factor structure must be treated with caution.

In conclusion, the NSUQ is comprehensive, theory driven, flexible and able to be used in various samples with various substances. In terms of construct validity, there is initial evidence in relation to the NSUQAlcohol Motives and, to a lesser extent, the NSUQ-Cannabis Motives, which have an acceptable fit and are interpretable. The measure demonstrates promise, particularly for research investigating the motives associated with specific substances use. It could potentially be used in clinical settings for investigating the type of beliefs that people with substance use difficulties may hold about various substances. Further research is initially required to address the limitations of the current study.

\section{Acknowledgments}

The author(s) received no financial support for the research, authorship, and/or publication of this article.

\section{Conflict of interests}

The author(s) declared no potential conflicts of interest with respect to the research, authorship, and/or publication of this article. 


\section{References}

1. Strote J, Lee JE, Wechsler H. Increasing MDMA use among college students: Results of a national survey. J Adolesc Health. 2002;30:64-72.

2. Hingson $R$, Heeren $T$, Winter $M$, Wechsler $H$. Magnitude of alcohol-related mortality and morbidity among U.S college students ages 18-24: Changes from 1998 to 2001. Annu Rev Public Health. 2005;26:259-79.

3. Presley CA, Meilman PW, Lyerla R, Cashin JR. Alcohol and Drugs on American College Campuses: Use, Consequences, and Perceptions of the Campus Environment, Volume III: 1991-93. Rockville, USA: NCRJS; 1996.

4. Cox WM, Klinger E. A Motivational Model of Alcohol Use. J Abnorm Psychol 1988;97:168-80.

5. Müller CP, Schumann G. Drugs as instruments: A new framework for non-addictive psychoactive drug use. Behav Brain Sci. 2011;34:293-310.

6. Home Office. Drug Misuse Declared: Findings from the 2011/12 Crime Survey for England and Wales [Internet] 2012. [cited November $18^{\text {th }} 2019$ ]. Available from:https://assets.publishing.service. gov.uk/government/uploads/system/uploads/ attachment_data/file/147938/drugs-misuse-dec1112-pdf.pdf

7. Simons JS, Gaher RM, Correia CJ, Hansen CL, Christopher LH, Christoper MS. An affective-motivational model of marijuana and alcohol problems among college students. Psychol Addict Behav. 2005;19:326-34.

8. Simons J, Correia CJ, Carey KB. A comparison of motives for marijuana and alcohol use among experienced users. Addict Behav. 2000;25:153-60.

9. Lorenzo-Seva U, Ferrando PJ. FACTOR: A computer program to fit the exploratory factor analysis model. Behav Res Methods. 2006;38:88-91.

10. Muthen B, Kaplan D. A comparison of some methodologies for the factor analysis of non normal Likert variables: A note on the size of the model. Br J Math Stat Psychol. 1992;45:19-30.

11. Mardia KV. Measures of multivariate skewness and kurtosis with applications. Biometrika. 1970;57:519-30.

12. Baglin J. Improving your exploratory factor analysis for ordinal data: A demonstration using FACTOR. Pract Assessment Res Eval. 2014;19:1-15.
13. Field A. Discovering statistics using IBM SPSS statistics. Statistics. London: Sage Publishing; 2013.

14. National Health Services. Calories in alcohol. [Internet] 2016. [cited November 18 $8^{\text {th }}$ 2019]. Available from: https://www.nhs.uk/live-well/alcohol-support/calories-in-alcohol/

15. Julien RM. A primer of drug action: A concise, nontechnical guide to the actions, uses, and side effects of psychoactive drugs (7th ed.). New York: Holt Paperbacks; 1995. p. 512.

16. Parrott A, Morinan A, Moss M, Scholey A. Understanding Drugs and Behaviour. New York, USA: John Wiley \& Sons Inc; 2004.

17. Beavers AS, Lounsbury JW, Richards JK, Huck SW, Skolits GJ, Esquivel SL. Practical considerations for using exploratory factor analysis in educational research. Pract Assessment Res Eval. 2013;18:113.

18. Henson RK, Roberts JK. Use of exploratory factor analysis in published research: Common errors and some comment on improved practice. Educ Psychol Meas. 2006;66:393-416.

19. Ford JK, MacCallum RC, Tait M. The application of exploratory factor analysis in applied psychology: A critical review and analysis. Pers Psychol. 1986;39:291-314.

20. Fabrigar LR, MacCallum RC, Wegener DT, Strahan EJ. Evaluating the use of exploratory factor analysis in psychological research. Psychol Methods. 1999;4:272-99.

21. Kaiser HF. The Application of Electronic Computers to Factor Analysis. Educ Psychol Meas. 1960;20:141-51.

22. Osborne JW. Best Practices in Exploratory Factor Analysis. Create Space Independent Publishing Platform; 2014. p. 150.

23. Lorenzo-Seva U. How to report the percentage of explained common variance in exploratory factor analysis. Technical Report. Department of Psychology, Universitat Rovira i Virgili, Tarragona. [Internet] 2013. [cited November $18^{\text {th }}$ 2019]. Available from:http://psico.fcep.urv.es/utilitats/ factor/documentation/Percentage_of_explained_ common_variance.pdf

24. Shapiro A, Ten Berge JMF. Statistical inference of minimum rank factor analysis. Psychometrika. 2002;67:79-94. 
25. Cole DA. Utility of Confirmatory Factor Analysis in Test Validation Research. J Consult Clin Psychol. 1987;55:584-94.

26. Norusis MJ. Spss Advanced Statistics: Student Guide. Indianapolis, USA: SPSS Incorporated; 1993. p. 506.

27. Floyd FJ, Widaman KF. Factor analysis in the development and refinement of clinical assessment instruments. Psychol Assess. 1995;7:286-99.

28. Rummel RJ. Applied Factor Analysis. Evanston, USA: Northwestern University Press; 1970. p. 617

29. Cochrane C, Malcolm R, Brewerton T. The role of weight control as a motivation for cocaine abuse. Addict Behav. 1998;23:201-7.

30. McFadden D. "The World is Catching Up now": Acceptance Growing for Rastafarians. The Cannabist [Internet]. 2014 [cited November 18 $8^{\text {th }}$ 2019]. Available from: https://www.thecannabist. co/2014/09/15/jamaica-rastafarian-religion-marijuana-acceptance/19678/

31. Suhr DD. Exploratory or Confirmatory Factor Analysis [Paper 200-31] Proceedings of the Thirty-First Annual SAS Users Group International Conference [Internet]. 2006 [cited November $18^{\text {th }}$ 2019]. Available from: https://support.sas.com/ resources/papers/proceedings/proceedings/ sugi31/200-31.pdf

32. Guadagnoli E, Velicer WF. Relation of Sample Size to the Stability of Component Patterns. Psychol Bull. 1988;103:265-75.

33. MacCallum RC, Tucker LR. Representing sources of error in the common-factor model: Im- plications for theory and practice. Psychol Bull. 1991;109:502-11.

34. MacCallum RC, Widaman KF, Zhang S, Hong S. Sample size in factor analysis. Psychol Methods. 1999;4:84-99.

35. Kong G, Bergman A. A motivational model of alcohol misuse in emerging adulthood. Addict Behav. 2010;35:855-60.

36. Lee CM, Neighbors C, Woods BA. Marijuana motives: Young adults' reasons for using marijuana. Addict Behav. 2007;32:1384-94.

37. Chabrol H, Ducongé E, Casas C, Roura C, Carey $\mathrm{KB}$. Relations between cannabis use and dependence, motives for cannabis use and anxious, depressive and borderline symptomatology. Addict Behav. 2005;30:829-40.

38. Simons J, Correia CJ, Carey KB, Borsari BE. Validating a Five-Factor Marijuana Motives Measure: Relations with use, problems, and alcohol motives. J Couns Psychol. 1998;19:265-273.

39. Ham LS, Zamboanga BL, Olthuis JV, Casner HG, Bui N. No fear, just relax and play: Social anxiety, alcohol expectancies, and drinking games among college students. J Am Coll Heal. 2010;58:473-9.

40. Norman P, Conner MT, Stride CB. Reasons for binge drinking among undergraduate students: An application of behavioural reasoning theory. $\mathrm{Br} \mathrm{J}$ Health Psychol. 2012;17:682-98.

41. Reise SP, Waller NG, Comrey AL. Factor analysis and scale revision. Psychol Assess. 2000;12:287-97.

\section{Motivi u osnovi rekreacijske konzumacije alkohola i kanabisa}

Sažetak- Sekcija "motivi" koja je dio Newcastle upitnika o upotrebi supstanci (NSUQ) razvijena je na novoj teorijskoj osnovi instrumentalnih motiva. Cilj ovog istraživanja je bio istražiti latentnu strukturu faktora motiva upotrebe alkohola i kanabisa. NSUQ-Alkohol je ispunilo 285 sudionika, dok je njih 62 također ispunilo NSUQ-Cannabis. Eksplorativna faktorska analiza (EFA) učinjena je programom FACTOR, verzija 9.2. Sekcija motivi NSUQ-Alkohol sastojala se od 14 predmeta. Zadržan je trofaktorski model: socijalni faktor objašnjava najveću varijancu $(3,28)$, potom zauzimanje perspektive $(3,13)$ te na kraju seksualni motiv $(1,85)$. Motivi NSUQ-kanabis sastojali su se od 16 predmeta koji su također podijeljeni u tri faktora. Faktor zauzimanja perspektive doprinio je najvećoj varijansi $(2,72)$, a potom ga slijedi faktor socijalnog motiva $(2,47)$ te faktor 
fizičkog motiva $(1,05)$. Navedeni čimbenici potencijalno odražavaju motive učenika koji rekreativno konzumiraju alkohol i kanabis.

Ključne riječi: instrumentalni motivi, rekreativna uporaba supstanci, motivi za alkohol, motivi za kanabis 